POEF-SH-12

MARTIN MARIETTA

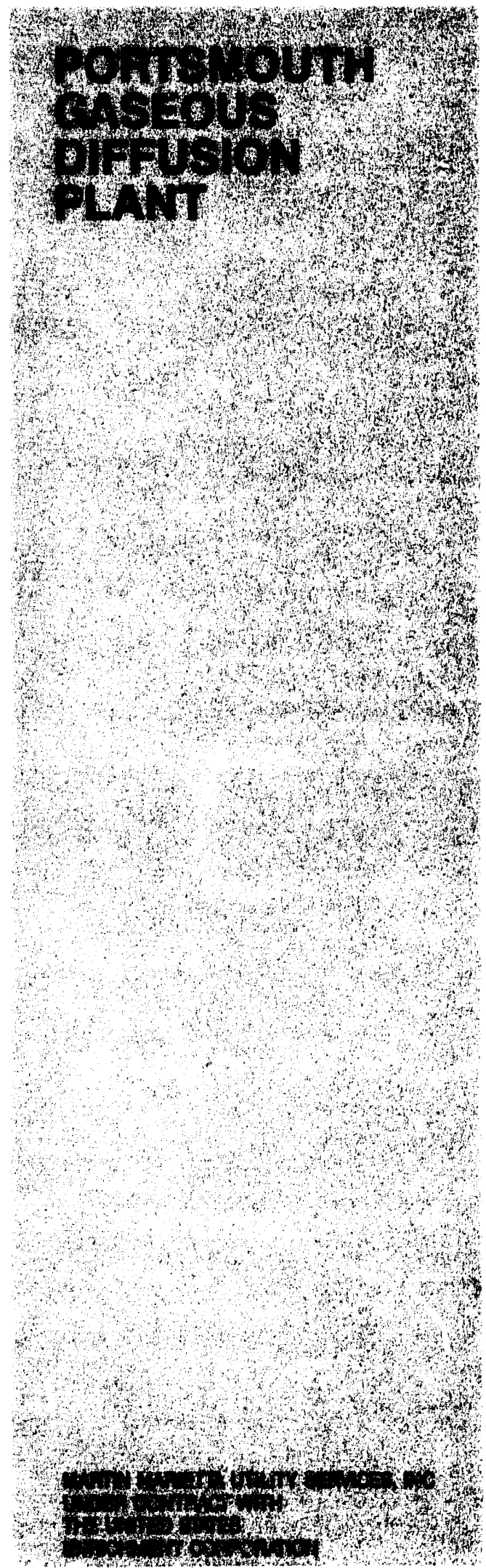

\author{
By \\ Scott B. Negron
Robert W. Tayloe, Jr. \\ Scott B. Negron
Robert W. Tayloe, Jr.
}

January 1994 


\section{NOTCE}

This report wes prepared es in secount of work sponsored by an eveney of the Unitud Stries Covemment. Nolther the United Stetes Covernment ner eny eseney thoreof, nor eny of their employees makes eny warrenty, expreas or implled, or escumses eny legd llabllty or reaponalbilly for the eccurecy, completeneses, or uschulness of eny information, apperatus, product, or process disclosed, or represents thet tis wes would not lifinge privetely owned rights. Roforence horein to any speclive commarcid product, process, or service by trade neme, tredemerk, menufecturer, or othernibe does not necesearily constitute or inply tis endoreament, recommendation, or fovoring by the United States Covemment or any egency thereof. The viows and aplinions of evthore expreseed horein do not necesearily state or reflect these of the Uniled stotes Government or eny agenoy thereof.

Avelioble to DOE and DOE Contractore from the Ofirce of solientific and Technied Information, P.0. Box 62, Oak Ridge, TN 37831; prices evallable from (615) 576-8401. FT8/626-8401.

Avalible to the public from the Nationd Technical Intormation Serviea, U.8. Depertiment of Commorce, 5285 Port Royd Road, Springifleld, VA 22101. 


\title{
Analysis of the Proposed Relocation of the Neutron Criticality Clusters in the Process Buildings for the Portsmouth Gaseous Diffusion Plant
}

\author{
By \\ Scott B. Negron \\ Robert W. Tayloe, Jr. \\ BATTELLE \\ 505 King Ave. Columbus, Ohio 43201 \\ Under Contract 0T0049 with \\ Martin Marietta Energy Systems, Inc.
}

January 1994

MARTIN MARIETTA UTILITY SERVICES, INC.

Portsmouth Gaseous Diffusion Plant

P. O. Box 628 Piketon, Ohio 45661

Under Contract No. USECHQ-93-C-0001

with the

UNITED STATES ENRICHMENT CORPORATION

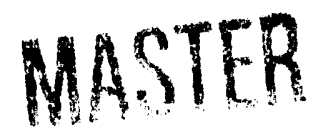


POEF-SH-12

\section{DISTRIBUTION}

\section{MARTIN MARIETTA UTILITY SERVICES, INC.}

\section{PORTSMOUTH}
R. Newvahner
C. Haught
R. Oxenham
R. Lemming

D. D'Aquila (10) Central Files (2)

X-710 Technical Library (2)

Technical Review (3)

\section{PADUCAH}
C. Dean (2)
T. Hines
D. Baltimore
S. Wachtel
S. Negron
W. Simmons
R. Tayloe
B. Lee
R. Denning
D. Lindenschmidt 
POEF-SH-12

\begin{abstract}
Radiation levels in Buildings X-326, X-330 and X-333 have been determined for the ANSI minimum accident of concern at both the current and the proposed locations of the criticality alarm system neutron detectors. This was performed in order to evaluate whether or not the detectors could be lowered from their current positions and still respond to the minimum accident of concern. Relocating the detectors could reduce the potential for worker injury when the approximately 90-pound alarms need to be removed for periodic maintenance. It could also decrease the incidence of battery failure from elevated temperatures which can exceed 160 degrees $F$.
\end{abstract}

At the proposed 1-meter elevation the detectors would be surrounded by the cells containing the cascade equipment; therefore, the detectors would be less responsive to a criticality event. The results of this analysis indicate that the detectors could be lowered from their current height of 5 meters to a height of 1 meter and still respond to the minimum accident of concern.

This analysis was performed using the MCNP monte carlo code with a source corresponding to a critical system of uranyl fluoride solutions of 1.2 , 3.0, and 4.95 weight percent U-235 enrichment. The neutron dose rates were evaluated at positions of 69 meters and 100 meters radially outward from the source at 5 meter and 1 meter heights. All neutron detectors located in the three process buildings are located within 100 meters from any potential criticality.

This report details the methodology used for this study, background on the data employed, and a comparison to a similar analysis performed in 1983 by R. M. Westfall and J. R. Knight at the Oak Ridge National Laboratory using the DOT-IV code. 


\section{TABLE OF CONTENTS}

Page

ABSTRACT $\ldots \ldots \ldots \ldots \ldots \ldots \ldots \ldots \ldots \ldots \ldots \ldots \ldots \ldots$ ii

1.0 CONCLUSIONS $\ldots \ldots \ldots \ldots \ldots \ldots \ldots \ldots \ldots \ldots \ldots \ldots \ldots$

2.0 INTRODUCTION $\ldots \ldots \ldots \ldots \ldots \ldots \ldots \ldots \ldots \ldots \ldots \ldots \ldots \ldots \ldots \ldots \ldots \ldots$

3.0 PROBLEM SPECIFICATIONS $\ldots \ldots \ldots \ldots \ldots \ldots \ldots \ldots \ldots$

4.0 METHODOLOGY $\ldots \ldots \ldots \ldots \ldots \ldots \ldots \ldots \ldots \ldots \ldots \ldots \ldots \ldots \ldots \ldots \ldots$

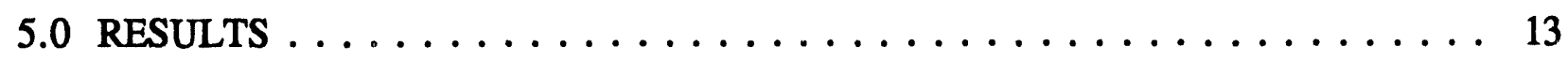

6.0 REFERENCES $\ldots \ldots \ldots \ldots \ldots \ldots \ldots \ldots \ldots \ldots \ldots \ldots \ldots \ldots$

APPENDIX A. MCNP INPUTS $\ldots \ldots \ldots \ldots \ldots \ldots \ldots \ldots \ldots \ldots \ldots \ldots$

APPENDIX B. RESPONSE FUNCTIONS $\ldots \ldots \ldots \ldots \ldots \ldots \ldots$

APPENDIX C. COMPARISON OF MCNP AND DOT-IV RESULTS $\ldots \ldots \ldots \ldots 27$ 


\section{LIST OF TABLES}

Page

Table 1. Maximum Source to Detector Distances for Buildings X-326, X-330,

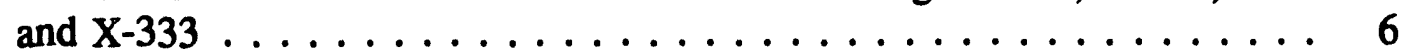

Table 2. Neutron Source Strengths $\ldots \ldots \ldots \ldots \ldots \ldots \ldots \ldots \ldots \ldots$

Table 3. Neutron Leakage Spectra $\ldots \ldots \ldots \ldots \ldots \ldots \ldots \ldots$

Table 4. Material Compositions ................... 9

Table 5. Dose Rates at Selected Positions $\pm 1 \sigma\left(\mathrm{mrad} \mathrm{h}^{-1}\right) \ldots \ldots \ldots \ldots$

Table A-1. MCNP Input Deck for 1.2 Percent Enrichment . . . . . . . . . . . 17

Table A-2. MCNP Input Deck for 3.0 Percent Enrichment $\ldots \ldots \ldots \ldots . \ldots 20$

Table A-3. MCNP Input Deck for 4.95 Percent Enrichment . . . . . . . . . 23

Table B-1. Henderson Flux-to-Dose Response Functions . . . . . . . . . . . . 26

Table C-1. MCNP/DOT-IV Comparison of Expected Neutron Dose Rates from Selected Critical Sources

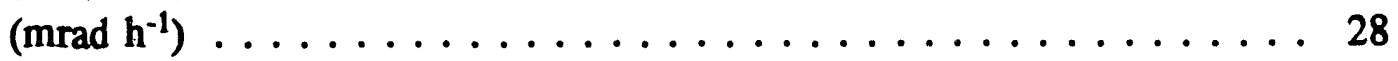

\section{LIST OF FIGURES}

Page

Figure 1. The MCNP Geometry Model $\ldots \ldots \ldots \ldots \ldots \ldots \ldots$ 


\subsection{CONCLUSIONS}

Results of the dose rate computations show that for all three enrichment sources evaluated, more than $5 \mathrm{mrad} \mathrm{h}^{-1}$ of neutron radiation would be present at heights from 1 meter out to 100 meters.

The criticality accident alarm detector set point is $5 \mathrm{mrad} \mathrm{h}^{-1}$. Consequently, all positions within this radius would meet the requirements set forth by the ANSI standard. All of the detectors currently in position in Buildings $\mathrm{X}-326, \mathrm{X}-330$, and $\mathrm{X}-333$ are within this 100 meter range from any possible criticality event within the building (Table 1).

The model used in this analysis is identical to that used in earlier analyses. These earlier analyses showed that the current location of the criticality alarm system would respond to a minimum accident of concern. 
POEF-SH-12

\subsection{INTRODUCTION}

This analysis was performed to determine whether or not the neutron detectors present in the $X-326, X-330$ and $X-333$ process buildings could be lowered from their current height of 5 meters to a lower height of 1 meter and still be responsive to a minimum accident of concern (Ref. 1). These neutron detectors are located above the cells that comprise the cascade diffusion plant and are accessible by catwalks and ladders.

Relocating the detectors could reduce the potential for worker injury when the approximately 90 pound alarms need to be removed for periodic maintenance. It could also decrease the incidence of battery failure from elevated temperatures which can exceed 160 degrees $\mathrm{F}$. At the proposed 1-meter elevation the detectors would be surrounded by the cells containing the cascade equipment; therefore, the detectors would be less responsive to a criticality event.

The criticality alarm system must be able to respond to the ANSI minimum accident of concern. ANSI Standard ANS-8.3-1986, "Criticality Accident Alarm System," provides guidance for the establishment and maintenance of systems in facilities engaged in the processing of fissionable materials (Ref. 2). Section 5.6 of the standard addresses the question of the minimum accident of concern.

5.6. Detection Criterion. Criticality alarm systems shall be designed to detect immediately the minimum accident of concern. For this purpose, in areas where material is handled or processed with only nominal shielding, the minimum accident may be assumed to deliver the equivalent of an absorbed dose in free air of $20 \mathrm{rad}$ at a distance of 2 meters from the reaction material in $60 \mathrm{~s}$. The alarm signal shall activate promptly when the dose rate at the detectors equals or exceeds a value equivalent to $20 \mathrm{rad} \mathrm{min}^{-1}$ at 2 meters from the reacting material.

This detection criterion establishes the reference criticality incident used for this study. In terms of average dose rate, the criticality event generates $1,200 \mathrm{rad} \mathrm{h}^{-1}$ of 
combined neutron and photon absorbed dose at positions 2 meters from the surface of the critical volume.

Another important consideration addressed by the standard is the ability of the detection system to avoid false alarms from background radiation through the use of appropriate discriminator trip point settings.

5.7.2. To minimize false alarms, the trip point may be set in the $\mathrm{rad} \mathrm{h}^{-1}$ range as long as the criterion of 5.6 is met. The alarm trip point of the rate sensing device should be more than $10 \mathrm{mrad} \mathrm{h}^{-1}$ above normal or operational background at the monitoring point.

The neutron background radiation levels within the cascade process buildings are less than $0.1 \mathrm{mrad} \mathrm{h}^{-1}$. An alarm set point of $5 \mathrm{mrad} \mathrm{h}^{-1}$ is used at the Portsmouth facility. There have not been any false criticality alarms at the Portsmouth facility as a result of high background radiation.

A third factor in the evaluation of the criticality alarm system is the shielding effect of process equipment located between the radiation source and the detectors. The location and spacing addressed in Section 5.8 of the ANSI standard.

5.8. Spacing. The location and spacing of detectors should be chosen to avoid the effect of shielding by massive equipment or materials. Low density materials of construction such as wood framing, thin interior walls, hollow brick tiles, etc., consistent with the selected alarm point and with the detection criterion.

The standard used for this report, ANSI/ANS-8.3-1986, supersedes the standard used for the 1983 Westfall report, ANSI/ANS-8.3-1979. However, the ANSI revision does not impact the procedures used for this analysis, nor does it impact the capability to make comparisons to the 1983 Westfall report. 


\subsection{PROBLEM SPECIFICATIONS}

The task of evaluating the radiation levels at the proposed lowered detector positions was achieved by the development of an MCNP model of a cascade enrichment building containing a source term describing the ANSI minimum accident of concern. This model is purposefully similar to that produced in 1983 by Westfall utilizing the DOT-IV transport code (Ref. 3). The purpose for developing the MCNP model similar to the DOT-IV model was to facilitate a fair comparison between results of the two analyses.

The building modeled is an approximation of several buildings (X-326, X-330, and $\mathrm{X}-333$ ) in which the proposed detector relocations would take place (Ref. 3). In the approximated model, the cell floor consists of 16.4-cm-thick concrete slabs supported on a steel grid. The cells containing the process equipment are approximately 30-meters long and 3.4-meters high. Longitudinally, the cells are separated by 6 meter wide aisles at a height of 5 meters above the surface of the cell floor. The upper portion of the building is essentially an open bay broken by some high capacity cranes and their support structure. The roof is located 16.5 meters above the surface of the cell floor.

Uranium enrichment below 1 weight percent U-235 is not considered to have the potential for achieving accidental criticality at the Portsmouth Gaseous Diffusion Plant. Much of the X-333 and the TAIlS part of X-330 process buildings have uranium of enrichment at 1 weight percent $U-235$ or less.

Nevertheless, in order to provide maximum flexibility in enrichment operations and storage of fissile heavy materials, criticality alarm coverage is provided for all of the process buildings. Thus it is assumed that an accidental criticality could occur anywhere within these buildings.

Since there is no fixed position for a potential criticality, the maximum distance to the nearest detector from any position must be determined. A key assumption used for this analysis is that all the detectors are equally sensitive, and that there is no angular dependance in detector sensitivity. 
POEF-SH-12

Table 1 lists the maximum distances for all detectors to potential critical sources in buildings X-326, X-330 and X-333 (Refs. 7-11). Due to the location of the detectors, no criticality accident can occur at a distance of more than 100 meters from any detector. Therefore, dose calculations at 100 meters from the detectors (at 5 meter and 1 meter heights) were used to evaluate whether the minimum accident of concern can be detected regardless of where it occurs within the buildings.

For comparison, additional detector location points were included in the model corresponding to positions used in the DOT-IV analysis. A comparison of the MCNP values to the DOT-IV values is given in Appendix C. Although two entirely different treatments were made of the problem (Monte Carlo versus Discrete Ordinates), the results compare favorably. A detailed discussion of the methodology employed in the Westfall DOT-IV analysis can be found in that document (Ref. 3).

An additional aspect of the criticality alarm system evaluation is the source characterization. The sources used in this analysis were the neutron leakage spectra of critical solutions of $\mathrm{UO}_{2} \mathrm{~F}_{2}-\mathrm{H}_{2} \mathrm{O}$ (uranyl fluoride) of $1.2,3.0$, and 4.95 weight percent enrichments. Currently, a maximum enrichment of 5.0 weight percent U-235 is being processed in the three buildings under consideration.

A 56-cm diameter stainless steel vessel containing a $\mathrm{U}(4.95) \mathrm{O}_{2} \mathrm{~F}_{2}$ solution with a uranium content of $1.04 \mathrm{~g} \mathrm{ml}^{-1}$ was used as the source of highest enrichment. A critical assembly of this dimension (SHEBA) was constructed at the Los Alamos Critical Experiments Facility for the uranium enrichment facilities in the early 1980s (Ref. 4). One of the principle uses of this device was to evaluate the criticality alarm system at the Portsmouth Gaseous Diffusion Plant (Ref.13).

Table 2 lists the neutron source strengths corresponding to critical power levels used in this investigation for each of the three sources. These values were used in converting the cell average fluxes from units of "per starting particle" to actual flux units of $\mathrm{n} \mathrm{cm}^{-2} \mathrm{sec}^{-1}$. Note that for increasing enrichment, the source strength decreases. 
POEF-SH-12

Table 1. Maximum Source to Detector Distances for Buildings X-326, X-330, and X-333

\begin{tabular}{|c|c|c|}
\hline Building & Cluster & Distance (meters) \\
\hline \multirow[t]{12}{*}{ Building X-326 } & 27-1-E & 79 \\
\hline & $27-1-W$ & 79 \\
\hline & 27-3-E & 79 \\
\hline & $27-3-w$ & 79 \\
\hline & 25-2-E & 79 \\
\hline & $25-2-W$ & 79 \\
\hline & 25-4-E & 84 \\
\hline & 25-4-W & 84 \\
\hline & $25-6-E$ & 84 \\
\hline & 25-6-W & 84 \\
\hline & $25-7-E$ & 49 \\
\hline & 25-7-W & 49 \\
\hline \multirow[t]{11}{*}{ Building $\times-330$} & 29-1-E & 98 \\
\hline & 29-1-W & 98 \\
\hline & 31-2-E & 98 \\
\hline & $31-2-w$ & 98 \\
\hline & $39-4-E$ & 90 \\
\hline & $31-4-W$ & 90 \\
\hline & 29-2-E & 90 \\
\hline & $29-2-W$ & 90 \\
\hline & 29-4-E & 90 \\
\hline & 29-6-E & 90 \\
\hline & 29-6-W & 90 \\
\hline \multirow[t]{8}{*}{ Building X-333 } & $33-1$ & 98 \\
\hline & $33-2$ & 98 \\
\hline & $33-3$ & 100 \\
\hline & $33-4$ & 100 \\
\hline & 33-5 & 100 \\
\hline & $33-6$ & 100 \\
\hline & $33-7$ & 98 \\
\hline & $33-8$ & 98 \\
\hline
\end{tabular}


Table 2. Neutron Source Strengths

\begin{tabular}{|c|c|c|}
\hline $\begin{array}{c}\text { Enrichment } \\
\text { (Weight Percent U-235) }\end{array}$ & $\begin{array}{c}\text { Power Level } \\
\text { (Watts Thermal) }\end{array}$ & $\begin{array}{c}\text { Strength } \\
\text { (n s) }\end{array}$ \\
\hline 4.95 & 2,100 & $4.86 \mathrm{E} 13$ \\
\hline 3.0 & 2,980 & $5.77 \mathrm{E} 13$ \\
\hline 1.2 & 22,190 & $6.49 \mathrm{E} 13$ \\
\hline
\end{tabular}

The radiation source is located on the model centerline at a height of $108 \mathrm{~cm}$ (91.5 cm above the floor) approximating the height of a container which would hold the $\mathrm{UO}_{2} \mathrm{~F}_{2}-\mathrm{H}_{2} \mathrm{O}$ solution. Table 3 lists the neutron leakage spectra normalized to one neutron. This is the same 27-group source used in the earlier DOT-IV analysis. The resultant fluxes and corresponding doses tallied by the MCNP runs also correspond to this 27-group structure.

The number densities of the elements used to make up the 5 materials employed in the model are listed in Table 4. All of the material inside the cell housings (equipment, structural members, etc.) has been homogenized to give the most conservative intervening shielding. This includes all tools, machinery, structural and other material normally located in an average cell. There is no fissile material present in the model. Consequently, all neutrons tracked in the model originate from the source (i.e., critical assembly) which is treated as a point. 
POEF-SH-12

Table 3. Neutron Leakage Spectra

\begin{tabular}{|c|c|c|c|c|}
\hline \multirow{2}{*}{$\begin{array}{c}\text { Group } \\
\text { No. }\end{array}$} & \multirow{2}{*}{$\begin{array}{c}\text { Upper Energy } \\
(\mathrm{eV})\end{array}$} & \multicolumn{3}{|c|}{ Enrichment - Woight Percent U-235 } \\
\hline & & $4.95 \%$ SHEBA & $3 \%$ Optimum H/U & $1.2 \%$ Optimum H/U \\
\hline 1 & $2.00 \mathrm{E}+7$ & 1.99E-2 & $1.78 \mathrm{E}-2$ & $1.66 \mathrm{E}-2$ \\
\hline 2 & $6.43 E+6$ & $1.11 \mathrm{E}-1$ & $1.05 \mathrm{E}-1$ & $9.45 \mathrm{E}-2$ \\
\hline 3 & $3.00 E+6$ & $1.21 \mathrm{E}-1$ & $1.18 \mathrm{E}-1$ & $1.08 \mathrm{E}-1$ \\
\hline 4 & $1.85 E+6$ & $6.45 \mathrm{E}-2$ & $6.42 E-2$ & $5.88 \mathrm{E}-2$ \\
\hline 5 & $1.40 E+6$ & $7.98 \mathrm{E}-2$ & 8.05E-2 & $7.43 \mathrm{E}-2$ \\
\hline 6 & $9.00 E+5$ & $1.14 \mathrm{E}-1$ & 1.19E-1 & $1.14 \mathrm{E}-1$ \\
\hline 7 & $4.00 E+5$ & $9.77 \mathrm{E}-2$ & $1.03 E-1$ & $1.01 \mathrm{E}-1$ \\
\hline 8 & $1.00 E+5$ & $6.51 \mathrm{E}-2$ & $7.00 \mathrm{E}-2$ & $7.12 \mathrm{E}-2$ \\
\hline 9 & $1.70 E+4$ & 4.66E-2 & $5.02 \mathrm{E}-2$ & $5.16 \mathrm{E}-2$ \\
\hline 10 & $3.00 E+3$ & 4.08E-2 & 4.40E-2 & 4.59E-2 \\
\hline 11 & $5.50 E+2$ & $3.77 E-2$ & $4.04 \mathrm{E}-2$ & $4.24 \mathrm{E}-2$ \\
\hline 12 & $1.00 E+2$ & $2.46 \mathrm{E}-2$ & 2.57E-2 & 2.69E-2 \\
\hline 13 & $3.00 E+1$ & $2.14 \mathrm{E}-2$ & $2.22 \mathrm{E}-2$ & $2.35 \mathrm{E}-2$ \\
\hline 14 & $1.00 E+1$ & 2.10E-2 & $2.10 \mathrm{E}-2$ & $2.19 E-2$ \\
\hline 15 & $3.05 E+0$ & $1.02 \mathrm{E}-2$ & $1.04 \mathrm{E}-2$ & 1.10E-2 \\
\hline 16 & $1.77 E+0$ & $5.93 E-3$ & $6.05 E-3$ & $6.41 \mathrm{E}-3$ \\
\hline 17 & $1.30 \mathrm{E}+0$ & $2.69 \mathrm{E}-3$ & $2.74 E-3$ & $2.92 \mathrm{E}-3$ \\
\hline 18 & $1.13 E+0$ & $2.34 E-3$ & $2.38 \mathrm{E}-3$ & $2.55 E-3$ \\
\hline 19 & $1.00 E+0$ & 4.33E-3 & 4.40E-3 & 4.70E-3 \\
\hline 20 & 8.00E-1 & $1.38 \mathrm{E}-2$ & $1.40 \mathrm{E}-2$ & $1.52 \mathrm{E}-2$ \\
\hline 21 & $4.00 \mathrm{E}-1$ & $4.00 \mathrm{E}-3$ & $4.04 E-3$ & $4.45 \mathrm{E}-3$ \\
\hline 22 & 3.25E-1 & $7.25 \mathrm{E}-3$ & 7.17E-3 & $8.17 \mathrm{E}-3$ \\
\hline 23 & 2.25E-1 & $2.30 \mathrm{E}-2$ & $2.04 E-2$ & $2.59 E-3$ \\
\hline 24 & $1.00 \mathrm{E}-1$ & $2.92 \mathrm{E}-2$ & $2.30 \mathrm{E}-2$ & $3.24 \mathrm{E}-2$ \\
\hline 25 & $5.00 \mathrm{E}-2$ & $1.70 \mathrm{E}-2$ & $1.28 \mathrm{E}-2$ & $1.89 E-2$ \\
\hline 26 & $3.00 \mathrm{E}-2$ & 1.32E-1 & $9.57 \mathrm{E}-3$ & $1.46 \mathrm{E}-2$ \\
\hline 27 & $1.00 \mathrm{E}-2$ & $2.36 \mathrm{E}-3$ & 1.67E-3 & 2.61E-3 \\
\hline & $1.00 \mathrm{E}-5^{*}$ & 1.00 & 1.00 & 1.00 \\
\hline
\end{tabular}

- Represents lower onergy limit to the sot. 
Table 4. Material Compositions

\begin{tabular}{|c|c|c|}
\hline Material & Element & $\begin{array}{l}\text { Number Density } \\
(\text { Atom barn } \\
\text { (Am } \mathbf{~ c m}^{-1} \text { ) }\end{array}$ \\
\hline \multirow{2}{*}{$\begin{array}{l}\text { Air } \\
\text { (Zone 1) }\end{array}$} & Nitrogen & $3.570 \mathrm{E}-5$ \\
\hline & Oxygen & $7.840 \mathrm{E}-6$ \\
\hline \multirow{9}{*}{$\begin{array}{l}\text { Concrete } \\
\text { (Zone 2) }\end{array}$} & Hydrogen & $1.487 \mathrm{E}-2$ \\
\hline & Carbon & $3.814 \mathrm{E}-3$ \\
\hline & Oxygen & 4.152E-2 \\
\hline & Sodium & $3.040 \mathrm{E}-4$ \\
\hline & Magnesium & $5.870 E-4$ \\
\hline & Aluminum & $7.350 E-4$ \\
\hline & Silicon & $6.037 \mathrm{E}-3$ \\
\hline & Calcium & $1.159 \mathrm{E}-2$ \\
\hline & Iron & $1.968 \mathrm{E}-4$ \\
\hline \multirow{2}{*}{$\begin{array}{l}\text { Steel } \\
\text { (Zone 3) }\end{array}$} & Carbon & $3.921 \mathrm{E}-3$ \\
\hline & Iron & $8.349 \mathrm{E}-2$ \\
\hline \multirow{10}{*}{$\begin{array}{l}\text { Homogenized Cell } \\
\text { (Zone 4) }\end{array}$} & Carbon & $6.230 \mathrm{E}-5$ \\
\hline & Fluorine & $8.880 E-5$ \\
\hline & Aluminum & 8.420 E-5 \\
\hline & Silicon & $1.666 \mathrm{E}-5$ \\
\hline & Chlorine & $8.800 \mathrm{E}-5$ \\
\hline & Chromium & $1.619 \mathrm{E}-4$ \\
\hline & Manganese & $1.703 \mathrm{E}-5$ \\
\hline & Iron & $5.934 E-4$ \\
\hline & Nickel & 4.563E-4 \\
\hline & Copper & $3.273 E-5$ \\
\hline \multirow{4}{*}{$\begin{array}{l}\text { Roof } \\
\text { (Zone 5) }\end{array}$} & Hydrogen & $4.288 \mathrm{E}-2$ \\
\hline & Carbon & $1.812 E-2$ \\
\hline & Oxygen & $1.896 \mathrm{E}-3$ \\
\hline & Iron & $2.783 E-2$ \\
\hline
\end{tabular}


POEF-SH-12

\subsection{METHODOLOGY}

The entire analysis has been performed with MCNP Monte Carlo Neutron Photon Transport Code in the neutron mode. MCNP utilizes combinatorial geometry for constructing detailed three dimensional models. Although an intricate 3-D model of each building could have been constructed, for this analysis the 2-D geometry modeled in the DOT-IV analysis was duplicated to facilitate a fair comparison.

Figure 1 shows the geometry of the model, although not to scale. In this crosssectional view, building height is represented in the $\mathrm{Z}$ (vertical) direction, while lateral dimensions are radially outward from the model centerline in the $\mathbf{R}$ direction. Thus, the model approximates a circular building with each area represented as a coaxial ring.

Aside from the mathematical treatment employed, the only difference between models is are the cross section data. The DOT-IV analysis employed a 27-group neutron library while MCNP utilizes a continuous energy library evaluated from the ENDF/B-V master files.

Separate cells were incorporated into the MCNP model that corresponded to the current and proposed detector locations. Fluxes within these cells were obtained as part of the requested output. MCNP evaluates flux within a cell by the track length estimate based on the number of particle collisions within the cell. These fluxes are given per starting particle $\left(\mathrm{cm}^{-2}\right)$ and must be multiplied by the original source strength $\left(\mathrm{n} \mathrm{s}^{-1}\right)$ to obtain actual flux units of $\mathrm{ncm}^{-2} \mathrm{~s}^{-1}$.

The fluxes evaluated in each of the requested cells were converted to neutron dose rates by multiplying by the Henderson response functions (Ref. 6). The resulting dose rates are in units of mrad $h^{-1}$. Printed with the dose rates are values of the statistical relative error at the $1 \sigma$ level. This is an estimate of the precision of the results and for a correctly modeled problem is proportional to the number of histories run in the problem. For detector problems, the suggested relative error for a tally is less than 5 percent (Ref. 5). 
POEF-SH-12

In order to obtain dose rates to within 5 percent relative error 500,000 particle histories were run. Such a large number was required in order to obtain enough collisions in the cells farthest away from the source. 
POEF-SH-12

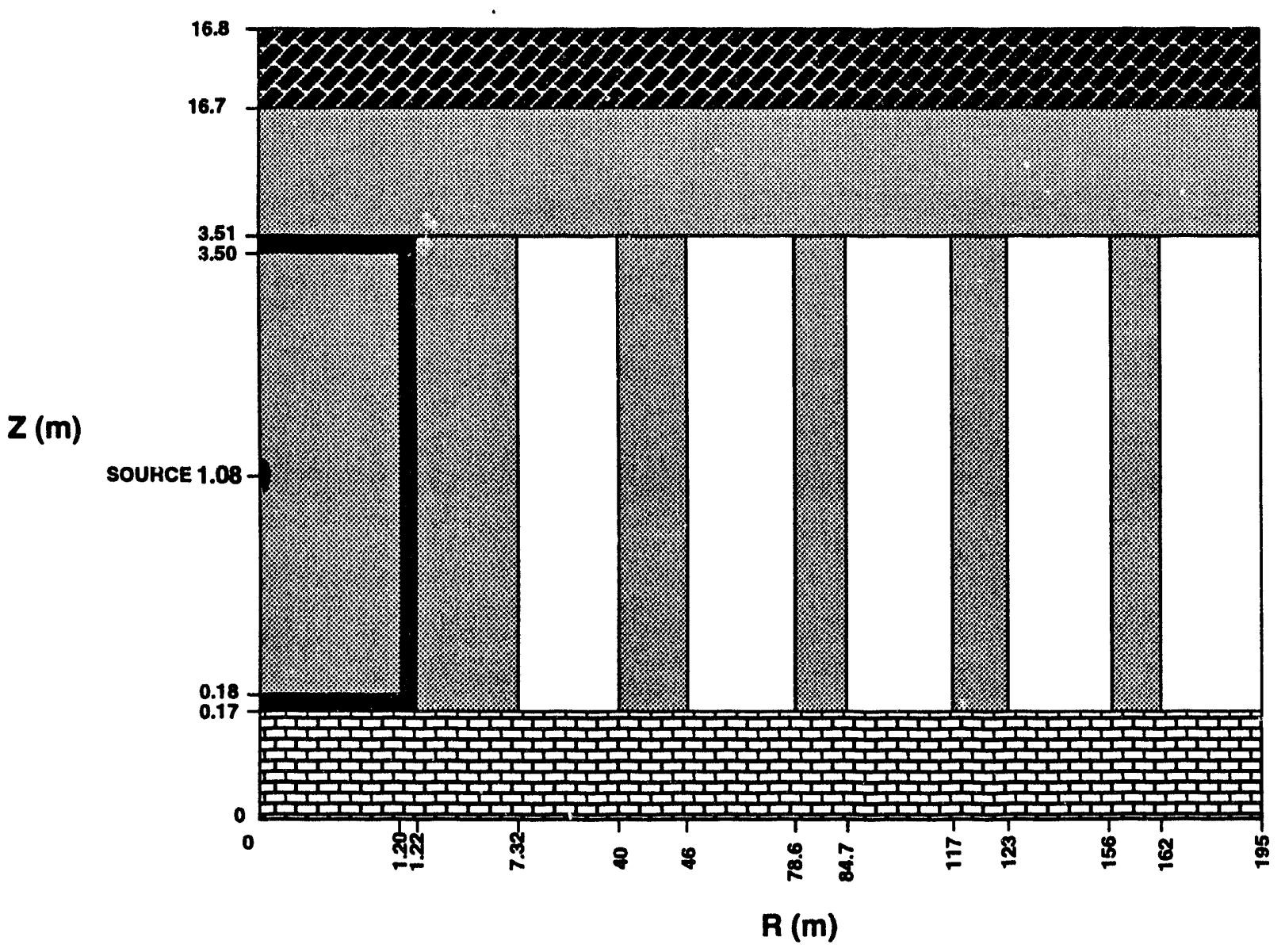

Figure 1. The MCNP Geometry Model 


\subsection{RESULTS}

The values obtained for the dose rates at selected positions are listed in Table 5. Along with each value is the accompanying relative error $(1 \sigma)$. The relative error is a function of the number of histories run, as well as distance of the edit to the source.

The dose rate value at each position decreases with increasing enrichment. This is due to the higher source strength at critical for each enrichment. According to Table 2, the lower enrichment source produces more neutrons per second than the higher enrichment source.

Table 5. Dose Rates at Selected Positions $\pm 1 \sigma\left(\operatorname{mrad} h^{-1}\right)$

\begin{tabular}{|l|c|c|c|}
\hline \multicolumn{1}{|c|}{$\begin{array}{c}\text { Detector } \\
\text { Position }\end{array}$} & \multicolumn{3}{|c|}{ Enrichment - Weight Percent U-235 } \\
\cline { 2 - 4 } & 1.2 & 3.0 & 4.95 \\
\hline $\begin{array}{l}2 \mathrm{~m} \text { Out } \\
\text { (Source Height) }\end{array}$ & $917 \pm 6.97$ & $890 \pm 6.41$ & $758 \pm 5.53$ \\
\hline $\begin{array}{l}69 \mathrm{~m} \text { Out } \\
(5 \mathrm{~m} \text { Height) }\end{array}$ & $215 \pm 6.82$ & $204 \pm 6.19$ & $178 \pm 5.35$ \\
\hline $\begin{array}{l}69 \mathrm{~m} \text { Out } \\
11 \mathrm{~m} \text { Height) }\end{array}$ & $60.4 \pm 2.06$ & $59.3 \pm 1.94$ & $51.3 \pm 1.68$ \\
\hline $\begin{array}{l}100 \mathrm{~m} \text { Out } \\
(5 \mathrm{~m} \text { Height) }\end{array}$ & $66.0 \pm 2.74$ & $59.9 \pm 2.29$ & $52.6 \pm 2.07$ \\
\hline $\begin{array}{l}100 \mathrm{~m} \text { Out } \\
11 \mathrm{~m} \text { Height) }\end{array}$ & $13.5 \pm 0.596$ & $13.2 \pm 0.621$ & $11.1 \pm 0.493$ \\
\hline
\end{tabular}




\subsection{REFERENCES}

1. F. Cordier interoffice memo to D. Aquila, "Proposed Relocation of the Neutron Criticality Clusters in the Process Buildings," POEF-592-93-27, Portsmouth Gaseous Diffusion Plant, July 1, 1993.

2. "American National Standard Criticality Accident Alarm System," ANSI/ANS-8.3-1979 (Rev. of N16.2-1969), American Nuclear Society, 1979.

3. Westfall, R.M. and J.R. Knight, "Radiation Levels in a Gaseous Diffusion Plant Assuming a Low-Enriched Criticality Event Corresponding to the ANSI - Standard Minimum Accident of Concern," ORNL/CSD/INF-82/7, Oak Ridge National Laboratory, January 1983.

4. Reiner, J.P., et al., "Dose Levels and Neutron Reaction Rate for HPRR and SHEBA," TANSAO 41-1-712, 1982.

5. Briesmeister, J. (Editor), "MCNP--A General Monte Carlo Code for Neutron and Photon Transport, Version 3A, LA-7396-M, Rev. 2, (September 1986, revised April 1991).

6. Henderson, B.J., "Conversion of Neutron or Gamma-Ray Flux to Absorbed Dose Rate," XDC-59-8-179, August 1959.

7. "Radiation Alarm System, X-326 Cell Floor - North Half" ORNL Drawing No. DX-220J-64E, Portsmouth Gaseous Diffusion Plant, 1961.

8. "Radiation Alarm System, X-330 Cell Floor - Units 29-1, 31-1, 31-2, 31-3, 31-4, and 31-5, " ORNL Drawing No. DX-220J-73E, Portsmouth Gaseous Diffusion Plant, 1961. 
POEF-SH-12

9. "Radiation Alarm System, X-330 Cell Floor - Units 29-2, 29-3, 29-4, 29-5, and 29-6," ORNL Drawing No. DX-220J-74E, Portsmouth Gaseous Diffusion Plant, 1961.

10. "Radiation Alarm System, X-333 Cell Floor - East Half," ORNL Drawing No. DX-220J-83E, Portsmouth Gaseous Diffusion Plant, 1961.

11. "Radiation Alarm System, X-333 Cell Floor - West Half," ORNL Drawing No. DX-220J-84E, Portsmouth Gaseous Diffusion Plant, 1961.

12. R.M. Westfall interoffice memo to W.C. Jordan, "Reaction Rates, Dose Factors and Low-Temperature Cross Sections," Oak Ridge Gaseous Diffusion Plant, March 14, 1983.

13. Malenfant, R.E. and H.M. Forehand, Jr., "Facility Description of a Solution Critical Assembly: SHEBA," LA-UR-81, August 1981. 
POEF-SH-12

\section{APPENDIX A. MCNP INPUTS}

The following three MCNP input files were used to generate the dose rate values in this report. A full description of the model is given in the main body of this report. This Appendix deals with the technical description of the input files.

Each of the three input files contain the same cell cards and surface cards that describe the basic model. The corresponding material cards are also common to all three files. All three files are set to run in the neutron mode, with the source definition (sdef) at point $(0,0,108)$. The energy distribution $(d 1)$ is listed in the sil card as a histogram distribution (h) corresponding to the 27-group structure listed in Table 3. The spl card contains the source probability distribution for the corresponding enrichment, listed in Table 3. These values are unique for each enrichment.

The f4: $n$ card indicates cell average flux tally on the cells listed. A brief description of each of the edit cells is given as a comment on the corresponding cell card. The $e 4$ card modifies the $f 4$ tally by editing only over the group structure specified by the $e 4$ entries.

The em 4 card contains the group-wise flux to dose response functions for the energy group structure of the $e 4$ card. These values are the response functions (listed in Appendix B), multiplied by the source strength (listed in Table 2), multiplied by the conversion factors of $3,600 \mathrm{sec} \mathrm{h}^{-1}$, and $10^{3} \mathrm{mrad} \mathrm{rad}^{-1}$. The $f c 4$ tally comment card has been utilized to indicate in the output file that the $f 4$ tallies have been modified by a response function, and the units of $\mathrm{mrad} \mathrm{h}^{-1}$ are printed.

Of particular importance to this investigation is the neutron importance card (imp:n). These entries assign weight windows to the surfaces of each cell in order to balance the neutron population between the source and the detector positions. This must be achieved to assure accuracy of the solution, for information once lost in transport cannot be regained. The importances listed in the imp: $n$ card balance the neutron population throughout the problem assuring adequate detector statistics. 
Table A-1. MCNP Input Deck for 1.2 Percent Enrichment

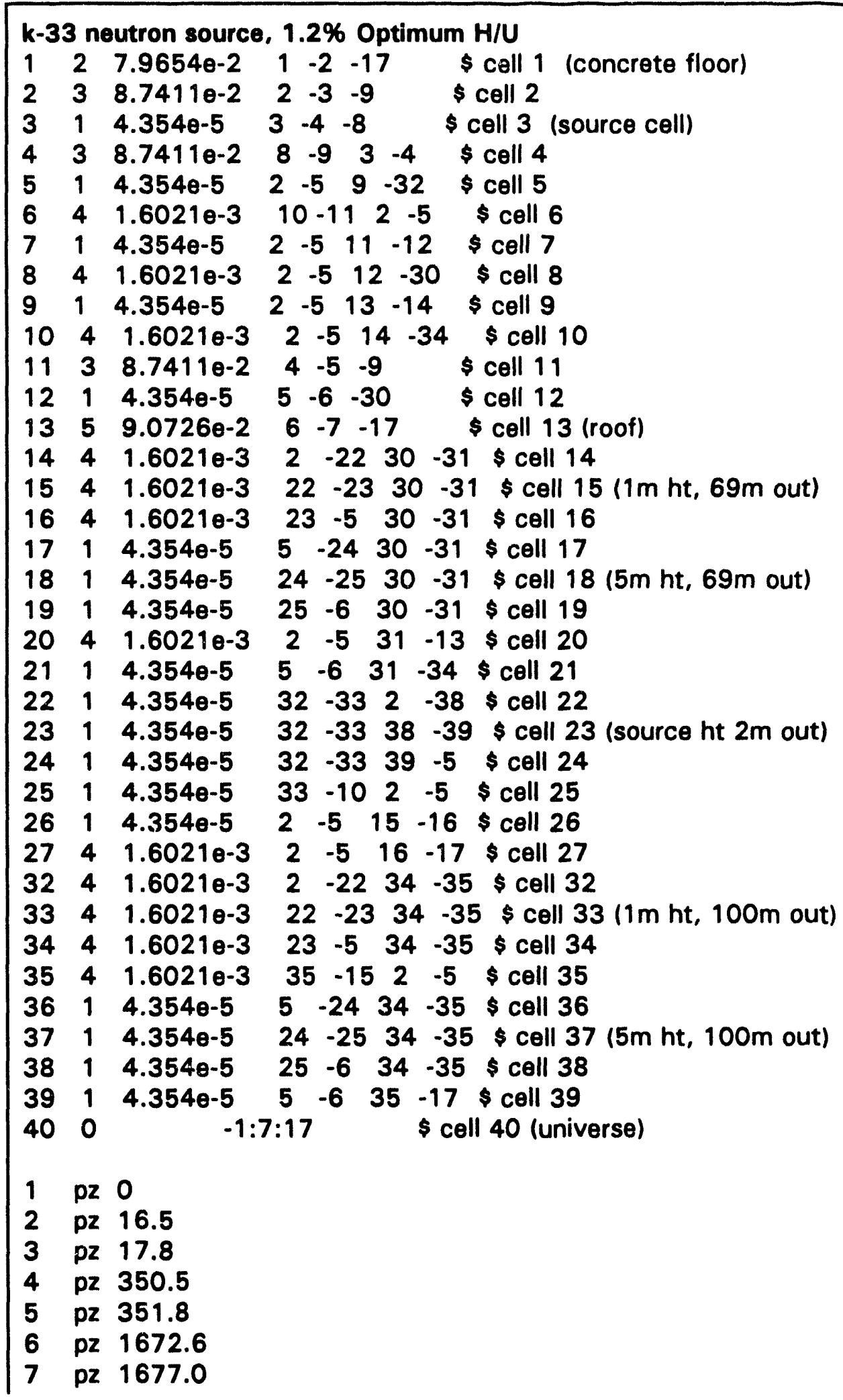




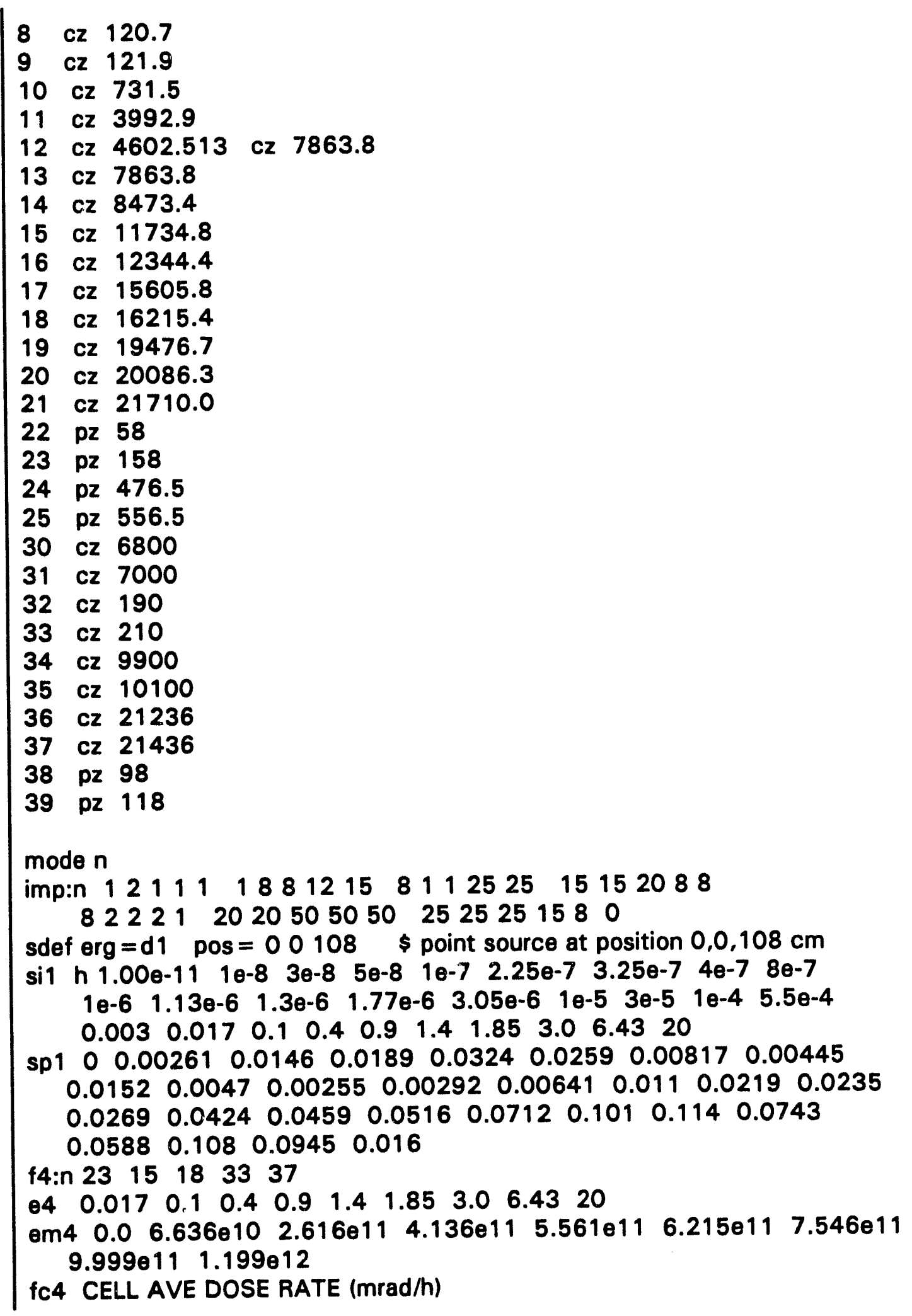




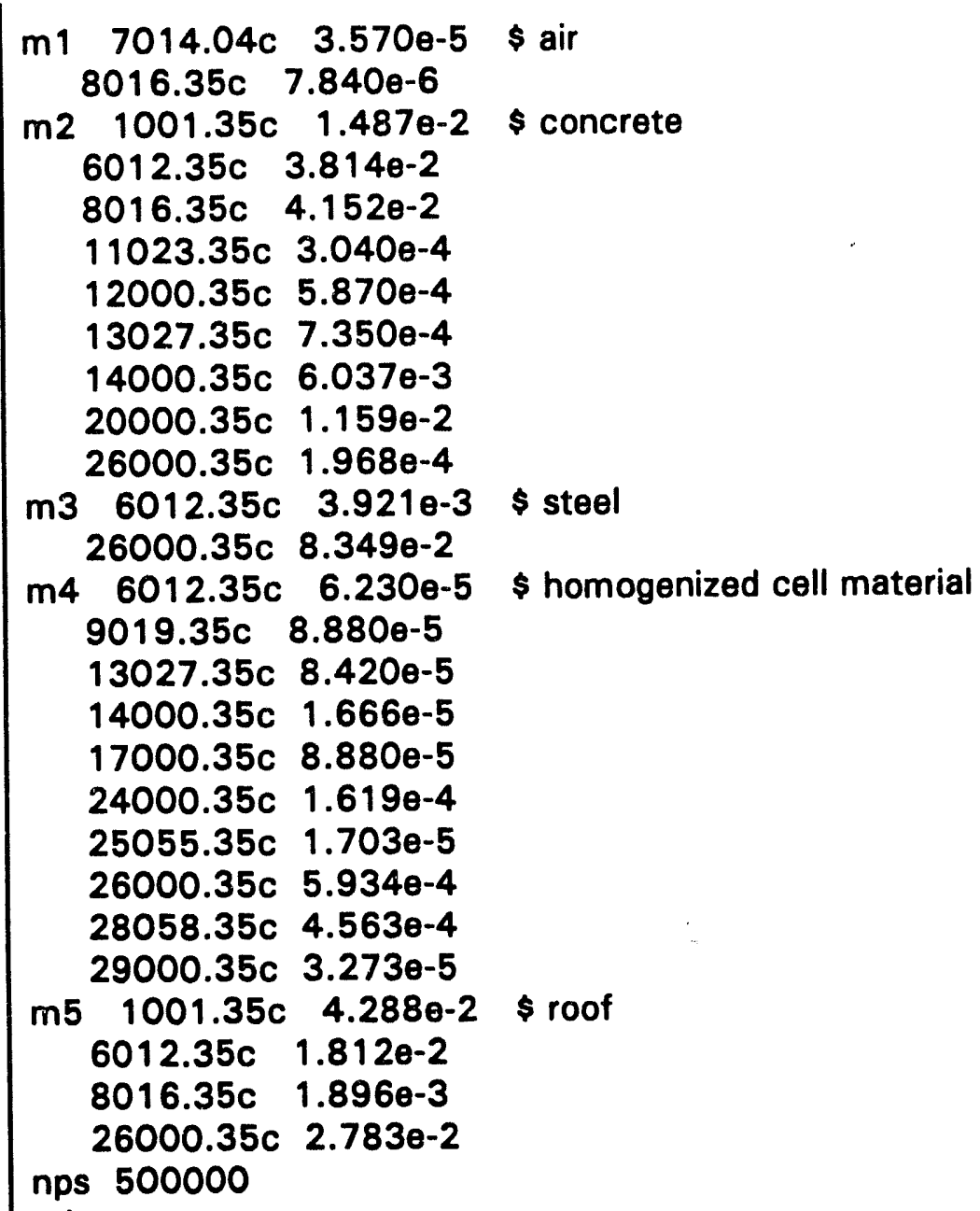


Table A-2. MCNP Input Deck for 3.0 Percent Enrichment

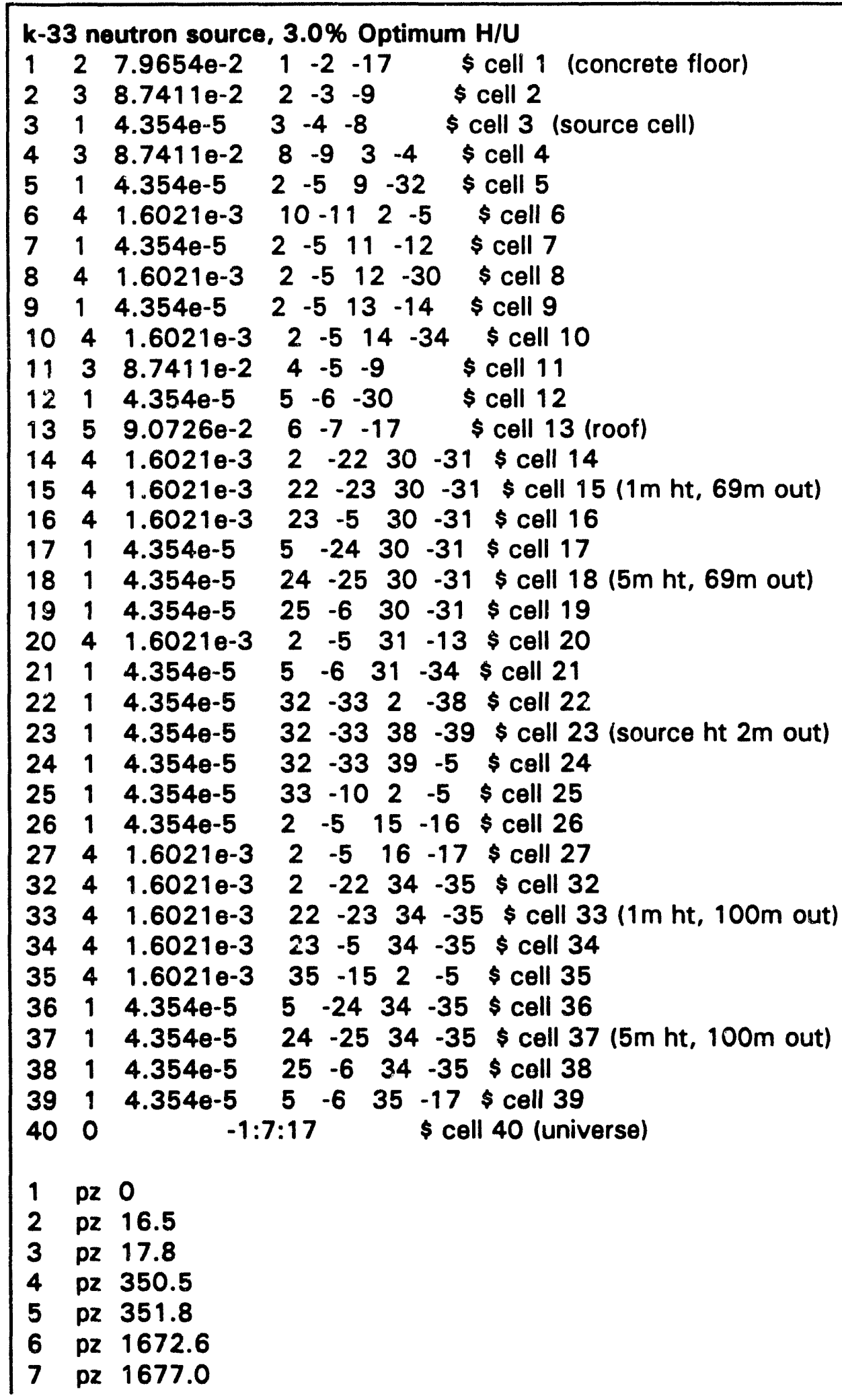




$$
\begin{aligned}
& \begin{array}{lll}
8 & \text { Cz } & 120.7
\end{array} \\
& 9 \text { Cz } 121.9 \\
& \begin{array}{lll}
10 & \text { cz } & 731.5
\end{array} \\
& 11 \text { Cz } 3992.9 \\
& 12 \text { cz } 4602.5 \\
& 13 \text { Cz } 7863.8 \\
& 14 \text { Cz } 8473.4 \\
& 15 \text { Cz } 11734.8 \\
& 16 \text { Cz } 12344.4 \\
& 17 \text { Cz } 15605.8 \\
& 18 \text { Cz } 16215.4 \\
& 19 \text { Cz } 19476.7 \\
& 20 \text { cz 20086.3 } \\
& 21 \text { cz } 21710.0 \\
& 22 \text { pz } 58 \\
& 23 \text { pz } 158 \\
& 24 \text { pz } 476.5 \\
& 25 \text { pz } 556.5 \\
& 30 \mathrm{cz} \quad 6800 \\
& \begin{array}{lll}
31 & \text { Cz } & 7000
\end{array} \\
& 32 \text { cz } 190 \\
& 33 \mathrm{cz} 210 \\
& 34 \mathrm{cz} 9900 \\
& 35 \text { cz } 10100 \\
& 36 \text { cz } 21236 \\
& 37 \text { Cz } 21436 \\
& 38 \mathrm{pz} 98 \\
& 39 \text { pz } 118
\end{aligned}
$$

mode $n$

imp:n 121111881215811252515152088

8222120205050502525251580

sdef erg $=\mathrm{d} 1$ pos $=00108$ \$ point source at position $0,0,108 \mathrm{~cm}$

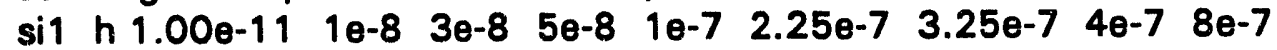

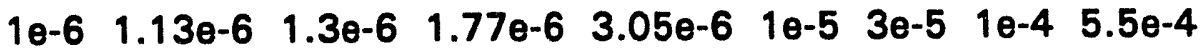
$\begin{array}{llllllllll}0.003 & 0.017 & 0.1 & 0.4 & 0.9 & 1.4 & 1.85 & 3.0 & 6.43 & 20\end{array}$

$\begin{array}{lllllllllll}\text { sp1 } & 0 & 0.00167 & 0.00957 & 0.0128 & 0.023 & 0.0204 & 0.00717 & 0.00404\end{array}$ $\begin{array}{lllllllll}0.014 & 0.0044 & 0.00238 & 0.00247 & 0.00605 & 0.0104 & 0.021 & 0.0222\end{array}$ $\begin{array}{llllllll}0.0257 & 0.0404 & 0.044 & 0.0502 & 0.07 & 0.103 & 0.199 & 0.0805\end{array}$ $\begin{array}{llll}0.0642 & 0.118 & 0.105 & 0.0178\end{array}$ f4: $\begin{array}{lllll}23 & 15 & 18 & 33 & 37\end{array}$ $\begin{array}{llllllllll}\theta 4 & 0.017 & 0.1 & 0.4 & 0.9 & 1.4 & 1.85 & 3.0 & 6.43 & 20\end{array}$ em4 $0.0 \quad 5.899 e_{10} 2.326 \theta 11 \quad 3.677 e 11 \quad 4.944 \theta 11 \quad 5.525 e 11 \quad 6.709 e 11$ $8.890 e 111.065 e 12$ fc4 CELL AVE DOSE RATE (mrad/h) 


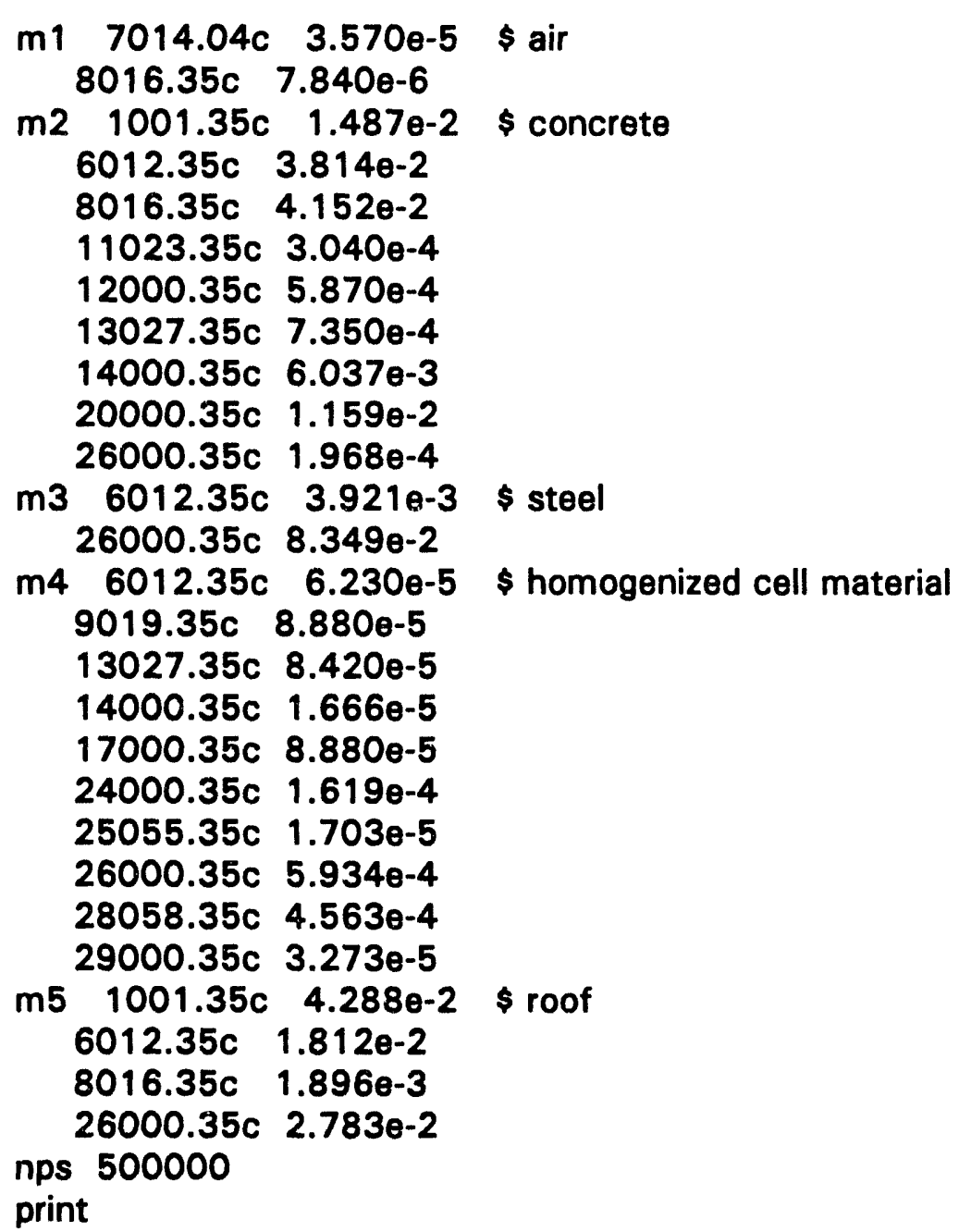


Table A-3. MCNP Input Deck for 4.95 Percent Enrichment

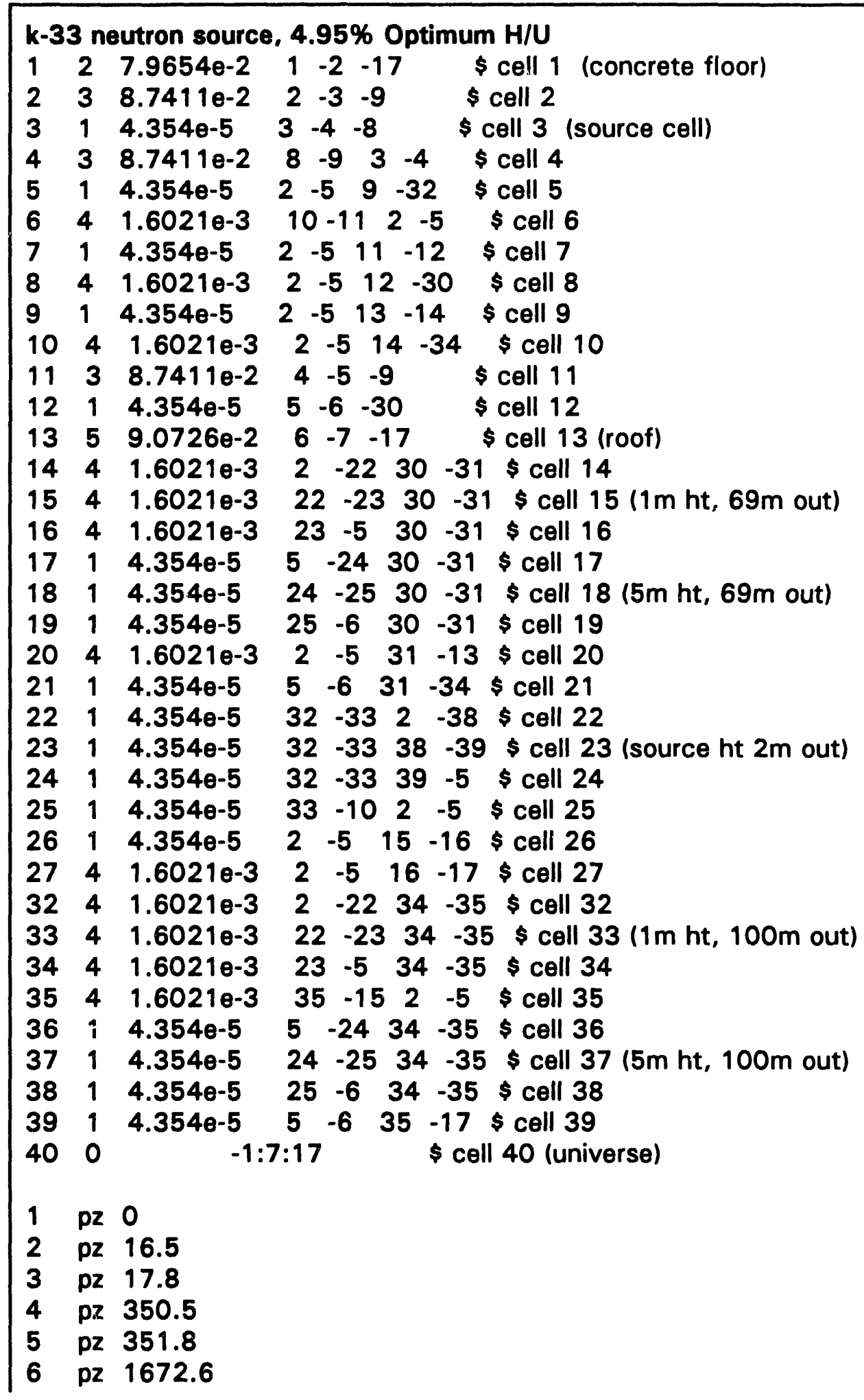




$$
\begin{aligned}
& \begin{array}{lll}
7 & \text { pz } & 1677.0
\end{array} \\
& 8 \text { Cz } 120.7 \\
& 9 \quad \text { Cz } 121.9 \\
& 10 \text { Cz } 731.5 \\
& 11 \text { cz } 3992.9 \\
& 12 \mathrm{cz} 4602.5 \\
& \begin{array}{lll}
13 & \text { Cz } & 7863.8
\end{array} \\
& \begin{array}{lll}
14 & \text { CZ } & 8473.4
\end{array} \\
& 15 \text { Cz } 11734.8 \\
& 16 \text { Cz } 12344.4 \\
& \begin{array}{lll}
17 & \text { Cz } & 15605.8
\end{array} \\
& 18 \text { Cz } 16215.4 \\
& 19 \text { cz } 19476.7 \\
& 20 \text { cz } 20086.3 \\
& 21 \text { cz } 21710.0 \\
& 22 \text { pz } 58 \\
& 23 \text { pz } 158 \\
& 24 \text { pz } 476.5 \\
& 25 \text { pz } 556.5 \\
& 30 \mathrm{cz} \quad 6800 \\
& 31 \text { cz } 7000 \\
& 32 \text { cz } 190 \\
& 33 \mathrm{cz} 210 \\
& \begin{array}{lll}
34 & \text { Cz } & 9900
\end{array} \\
& 35 \mathrm{cz} 10100 \\
& 36 \text { cz } 21236 \\
& 37 \text { Cz } 21436 \\
& 38 \text { pz } 98 \\
& 39 \text { pz } 118
\end{aligned}
$$

mode $n$

imp:n 121111881215811252515152088

8222120205050502525251580

sdef $e r g=d 1$ pos $=00108$ \$ point source at position $0,0,108 \mathrm{~cm}$

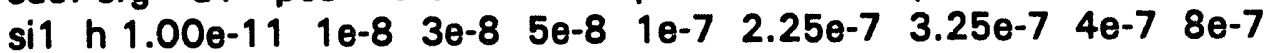

$$
\begin{array}{llllllllllll}
1 e-6 & 1.13 e-6 & 1.3 e-6 & 1.77 e-6 & 3.05 e-6 & 1 e-5 & 3 e-5 & 1 \epsilon-4 & 5.5 e-4 \\
0.003 & 0.017 & 0.1 & 0.4 & 0.9 & 1.4 & 1.85 & 3.0 & 6.43 & 20
\end{array}
$$

$\begin{array}{lllllllll}\text { sp1 } & 0 & 0.00236 & 0.0132 & 0.017 & 0.0292 & 0.023 & 0.00725 & 0.004\end{array}$

$\begin{array}{llllllll}0.0138 & 0.00433 & 0.00234 & 0.00269 & 0.00593 & 0.0102 & 0.021 & 0.0214\end{array}$

$\begin{array}{lllllllll}0.0246 & 0.0377 & 0.0408 & 0.0466 & 0.0651 & 0.0977 & 0.114 & 0.0798\end{array}$

$\begin{array}{llll}0.0645 & 0.121 & 0.111 & 0.0199\end{array}$

f4:n $\begin{array}{lllll}23 & 15 & 18 & 33 & 37\end{array}$

$\begin{array}{llllllllll}\theta 4 & 0.017 & 0.1 & 0.4 & 0.9 & 1.4 & 1.85 & 3.0 & 6.43 & 20\end{array}$

em4 $0.0 \quad 4.969 \mathrm{e} 10 \quad 1.959 \mathrm{e} 11 \quad 3.097 \mathrm{e} 11 \quad 4.164 \mathrm{e} 11 \quad 4.654 \mathrm{e} 11 \quad 5.651 \mathrm{e} 11$ $7.488 \theta 118.975 e 11$ 
fc4 CELL AVE DOSE RATE (mrad/h)

m1 7014.04c 3.570e-5 \$ air $8016.35 \mathrm{C} \quad 7.840 \mathrm{e}-6$

m2 $1001.35 \mathrm{c} \quad 1.487 \mathrm{e}-2$ \& concrete

$6012.35 c \quad 3.814 \theta-2$

$8016.35 \mathrm{C} \quad 4.152 \theta-2$

$11023.35 \mathrm{c} 3.040 \theta-4$

$12000.35 \mathrm{c} \quad 5.870 \theta-4$

$13027.35 c \quad 7.350 \theta-4$

$14000.35 c \quad 6.037 \theta-3$

$20000.35 c \quad 1.159 \theta-2$

26000.35 c $1.968 \theta-4$

m3 6012.35c $3.921 \theta-3$ \$ steel

26000.35 c $8.349 e-2$

m4 6012.35c 6.230e-5 \$ homogenized cell material $9019.35 \mathrm{c} \quad 8.880 \theta-5$ $13027.35 \mathrm{c} 8.420 \theta-5$ $14000.35 \mathrm{c} \quad 1.666 \theta-5$ $17000.35 \mathrm{c} 8.880 \mathrm{e}-5$ $24000.35 c \quad 1.619 e-4$ 25055.35c $1.703 \theta-5$ 26000.35 c $5.934 \theta-4$ 28058.35 c $4.563 e-4$ 29000.35 c $3.273 \theta-5$

m5 $1001.35 \mathrm{c} \quad 4.288 \mathrm{e}-2$ \& roof $6012.35 c \quad 1.812 \theta-2$ $8016.35 \mathrm{c} \quad 1.896 \mathrm{e}-3$ 26000.35 C $2.783 \theta-2$ nps $\mathbf{5 0 0 0 0 0}$ print 


\section{APPENDIX B. RESPONSE FUNCTIONS}

The Henderson Free-In-Air flux-to-dose response functions used in this investigation are listed in Table B-1. These values were obtained by re-bining the 37-group response functions listed in Reference 12. The re-bining of the group structure was performed graphically, plotting the functions as a histogram, then transforming the group structure by conserving the area under each group.

For energies below $0.1 \mathrm{MeV}$, the response functions are zero. Consequently, only 8 of the 27-neutron groups used contribute to the dose rates evaluated.

Table B-1. Henderson Flux-to-Dose Response Functions for (27-Group)

\begin{tabular}{|c|c|c|}
\hline Group No. & $\begin{array}{c}\text { Energy Range } \\
\mathbf{M e V}\end{array}$ & $\begin{array}{c}\text { Response Function } \\
\text { Rad } \mathbf{~ n}^{-1} \mathbf{c m}^{\mathbf{2}}\end{array}$ \\
\hline 1 & $20.0-6.43$ & $5.13 \times 10^{-9}$ \\
\hline 2 & $6.43-3.00$ & $4.28 \times 10^{-9}$ \\
\hline 3 & $3.00-1.85$ & $3.23 \times 10^{-9}$ \\
\hline 4 & $1.85-1.40$ & $2.66 \times 10^{-9}$ \\
\hline 5 & $1.40-0.9$ & $2.38 \times 10^{-9}$ \\
\hline 6 & $0.9-0.4$ & $1.77 \times 10^{-8}$ \\
\hline 7 & $0.4-0.1$ & $1.12 \times 10^{-9}$ \\
\hline 8 & $0.1-0.017$ & $2.84 \times 10^{-10}$ \\
\hline 9.27 & $0.017-1 \times 10^{-11}$ & 0.000 \\
\hline
\end{tabular}




\section{APPENDIX C. COMPARISON OF MCNP AND DOT-IV RESULTS}

Part of the methodology of this analysis was to follow as closely as possible the modelling employed in the 1982 Westfall analysis. This was done so that values derived from the MCNP calculations could be compared to those obtained in the Westfall analysis. For this reason the 3-D MCNP model exactly duplicates the DOT-IV R-Z geometry, shares the same material number densities, and shares the same source description. The only differences in the models are the cross-section sets used, and the type of mathematical treatment employed by the separate codes (transport vs. Monte Carlo).

Over the years MCNP has been extensively benchmarked to numerous critical experiments and various Sn transport codes, generally comparing quite well. Not surprisingly, the results obtained in this MCNP analysis compare rather well with the DOT-IV calculations. Table C-1 shows values obtained at selected points from the MCNP and DOT-IV analyses for each enrichment out to 138 meters. Only the 5-meter height positions are shown as the lowered 1-meter height values are not listed in the DOT-IV report.

The dose rate values compare to within a difference of less than 4 percent out to 100 meters, which corresponds to the maximum distance of a potential criticality to the nearest neutron detector. All conclusions drawn in this report are made from calculations within 100 meters from the critical source.

MCNP predicts higher dose rate values past 100 meters, by more than 50 percent at 138 meters. This is possibly due to the handling of the ray effects associated with scattering. The effect is undoubtedly pronounced due to the greater distance from the source. However, these differences do not have any effect on the conclusions drawn on the calculations out to 100 meters. 
Table C-1. MCNP/DOT-IV Comparison of Expected Neutron Dose Rates from Selected Critical Sources (mrad h $\mathbf{h}^{-1}$ )

\begin{tabular}{|c|cc|cc|cc|}
\hline $\begin{array}{c}\text { Source } \\
\text { to } \\
\text { Dotector } \\
\text { Distences }\end{array}$ & \multicolumn{2}{|c|}{$\begin{array}{c}\text { Source U-235 Enrichment } \\
\text { 1.2 Percent } \\
\text { MCNP }\end{array}$} & \multicolumn{2}{|c|}{$\begin{array}{c}\text { Source U-235 Enrichment } \\
\text { 3.0 Percent } \\
\text { MCNP }\end{array}$} & \multicolumn{2}{|c|}{$\begin{array}{c}\text { Source U-235 Enrichment } \\
\text { 4.95 Percent } \\
\text { DOT }\end{array}$} \\
\hline $2 \mathrm{~m}$ & 917 & 900 & 890 & 860 & 758 & 730 \\
\hline $69 \mathrm{~m}$ & 215 & 214 & 204 & 208 & 178 & 175 \\
\hline $100 \mathrm{~m}$ & 66 & 65.6 & 59.9 & 58.3 & 52.6 & 51.0 \\
\hline $138 \mathrm{~m}$ & 17.2 & 8.4 & 16.3 & 8.1 & 13.8 & 6.8 \\
\hline
\end{tabular}




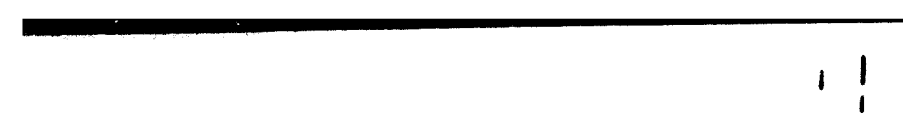
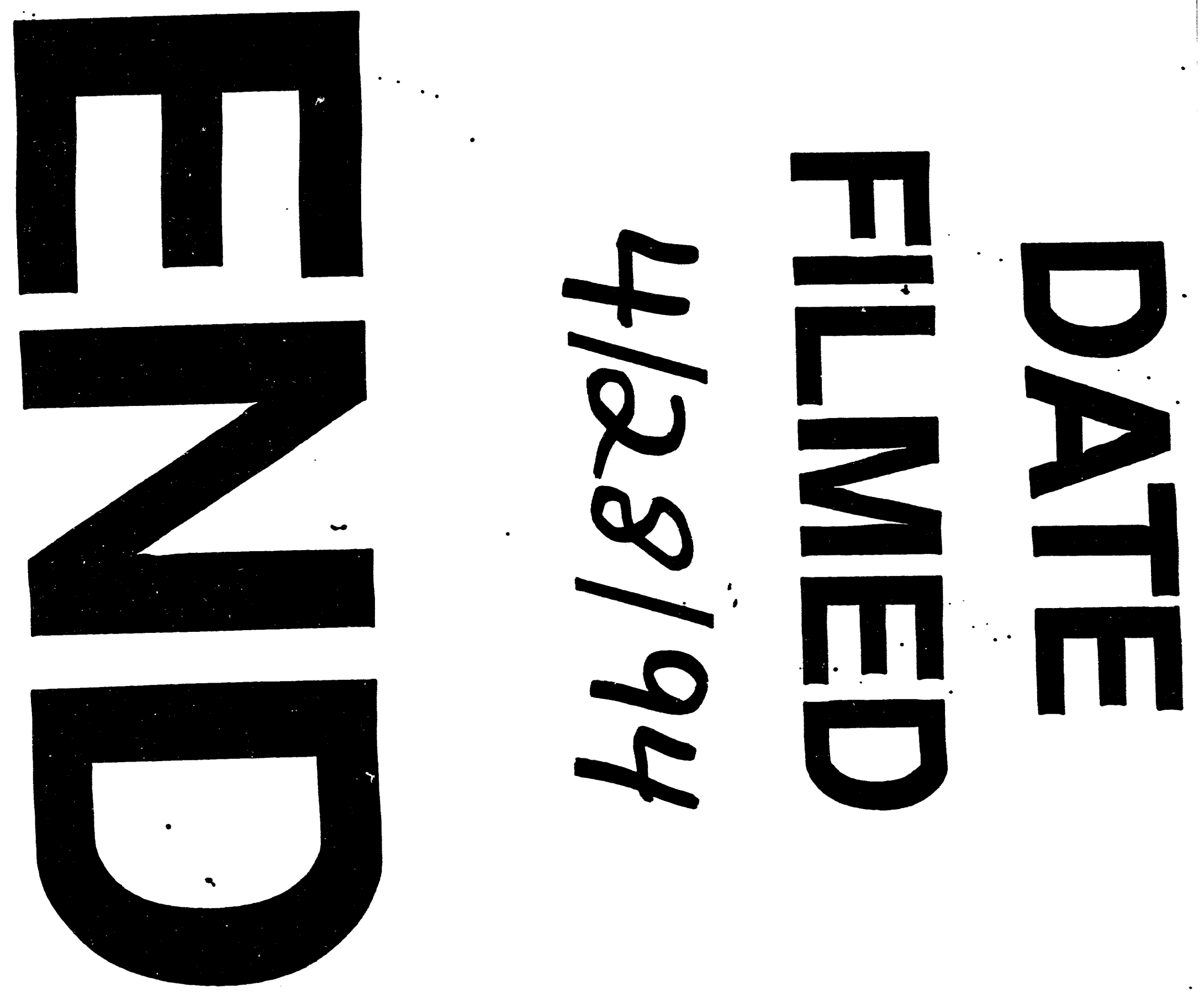
